\title{
神経筋移植術
}

\begin{abstract}
田中 信三
要 約 : 反回神経切除後の嗄声を予防するため, 傍声門間隙への神経筋移植法を 8 例に行っ た. 約 $1 \times 2 \mathrm{~cm}$ 大の胸骨舌骨筋を頸神経罠を付けた状態で採取し, 甲状軟骨板を前方に譒転・ 挙上して傍声門間隙にいたり, 神経筋を甲状披裂筋の外方に縫合し移植した。全例が甲状腺癌 で術前から声帯麻痺を生じていた。神経切除側の胸骨舌骨筋を使用したものが 4 例, 非切除側 から神経筋を切除側へ廻したものが 4 例あった。 術後, 全例で, 音声の聴覚印象は軽度嗄声, 最長持続発声時間と平均呼気流率はほほ正常であった。経過観察中に顕著な悪化例はなかった が，2 例に音声の聴覚印象と平均呼気流率が軽度悪化する傾向があった。いずれも, 非切除側 の神経筋を用いた例であった. 自分の声に不満を訴えた例はなかった。
\end{abstract}

索引用語 : 神経筋, 傍声門間隙, 胸骨舌骨筋, 反回神経切除, 嗄声予防

\section{Nerve-muscle Graft into Paraglottic Space after Recurrent Laryngeal Nerve Resection}

\section{Shinzo Tanaka}

\begin{abstract}
In eight patients with thyroid cancer, a nerve-muscle pedicle was inserted into the paraglottic space immediately after recurrent laryngeal nerve resection in order to prevent hoarseness. The sternohyoid muscle, about $1 \times 2 \mathrm{~cm}$ in size, connecting to the ansa cervicalis nerve was grafted into the lateral edge of the thyroarytenoid muscle by way of retracting the thyroid ala anteriorily with the inferior horn incised. The sternohyoid muscle at the resected side was used in four patients and the muscle at the unresected side in the other four. After surgery, all patients demonstrated fairly good voices and almost normal phonatory functions. No remarkable deterioration occurred in either voice or phonatory functions, although in two patients with the sternohyoid muscle used at the unresected side, a phonatory function tended to be worse. None of the eight patients has complained about his or her voice after surgery.
\end{abstract}

Key words : nerve-muscle graft, paraglottic space, sternohyoid muscle, recurrent laryngeal nerve resection, prevention of hoarseness

京都大学大学院医学研究科耳鼻咽喉科・頭頸部外科：干 606-8507 京都市左京区聖護院川原町 54

Department of Otolaryngology, Head \& Neck Surgery, Postgraduate School of Medicine, Kyoto University : 54 Kawaharacho, Shogoin, Sakyo-ku, Kyoto 606-8507

2003 年 1 月 22 日受理 


\section{はじめに}

一側反回神経麻痺に対する神経筋移植術は 1977 年 に Tucker が初めて報告した ${ }^{1)}$.しかしながら, 甲状軟 骨板の下半部を切除するため喉頭の枠組みが破壊され る, 音声の改善が遅い, 陳旧性麻痺では効果が不確実 である，などの問題があり，これまでのところは広く 普及するにいたっていない.われわれは, Tucker とは 異なる方法で, 喉頭の枠組みを破壊することなく術直 後から音声の改善が得られる神経筋移植法を考案し た ${ }^{2,3)}$.すなわち，胸骨舌骨筋の一部を神経を付けたま ま麻痺側の傍声門間隙に挿入固定する方法である。本 法により, 術直後から声帯が内方へ移動し良好な声門 閉鎖が得られるとともに，神経筋を介して甲状披裂筋 への神経再支配が生じ声帯の萎縮が予防されることが 期待できる。神経の再支配は新鮮な麻痺ほど起こりや すいので, 比較的新鮮と考えられる甲状腺癌手術時の 反回神経切除例に本法を行ってきた. 術後の音声機能 を検討したので報告する。

\section{手術法と対象}

胸骨舌骨筋の下半部で頸神経罠が筇に入る部位を同 定し，およそ $1 \times 2 \mathrm{~cm}$ 大の胸骨舌骨筋を頸神経罠を 付けたまま採取する。頸神経罠を起始部まで剥離し神 経筋弁を作成する. 麻痺側 (神経切除側) の胸骨舌骨 筋が使用できないときは反対側の胸骨舌骨筋と頸神経 罠で神経筋弁を作成する。その場合は，甲状舌骨筋と 麻痺側の甲状軟骨上角の後方を潜らせて神経筋弁を麻 痺側へ移動する。

麻痺側の甲状咽頭筋を起始部で切離し甲状軟骨の後 側端と下角を露出する。輪状甲状関節の近くで下角を 切離し, 甲状軟骨を反対側へ䧽転しつつ挙上し, 麻痺 側の甲状披裂筋と側輪状披裂筋を露出する（図 1 中
央).神経筋を甲状披裂筋の外方で側輪状披裂筋の前上 方に挿入し, 4-0 ナイロン系で 1 ～2 針, これらの内転 筋群に縫合し固定する.甲状軟骨の眽転・挙上を解除 し，元の位置に戻す（図 1 右）.

本手術を行った 8 例を表 1 に示す。全例が，甲状腺 癌のために術前から一側の反回神経麻痺を生じてい た. 麻痺側の反回神経を合併切除し，その直後に神経 筋移植を行った。半数では神経切除側の胸骨舌骨筋を 移植したが，半数では切除側の前頸筋群への癌浸潤が 疑われたために反対側の胸骨舌骨筋を移植した。術後 に 1 例で両側反回神経麻痺が生じたが, 3 力月後に非 切除側の麻痺は回復した。高齢者の 1 例で術後に喉頭 浮腫が生じ，一時的に気管切開を行った。横隔神経切 除例，鎖骨切除例，肺胁骨転移例がそれぞれ 1 例ずつ あった。また， 8 例中 1 例は未分化癌が早期に再発し たため音声機能検査ができなかった。

\section{結果}

術後音声の聴覚印象は軽度嗄声 (G1) を示すものが 最も多かった. 8 例の聴覚印象の推移を図 2 に示す. 術後早期には軽度嗄声（G1）であったが 1 年以降に正 常（G0）と判断されたものが 2 例あった。逆に, 軽度 嗄声 (G1) から中等度嗄声 (G2) に悪化したものが 2 例あった。この 2 例はいずれも非切除側から胸骨舌骨 筋を移植した症例であった。

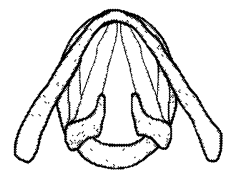

移植前

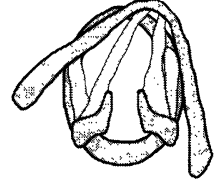

甲状軟骨の挙上

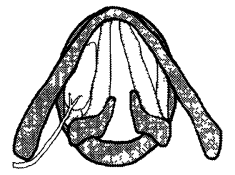

神経筋移植後
図 1 傍声門間隙への神経筋移植法

表 1 症例

\begin{tabular}{|c|c|c|c|c|c|c|}
\hline No & 性 & 歳 & 疾患名 & 術前麻痺 & 移植筋 & 備考 \\
\hline 1 & 男 & 62 & 甲状腺末分化癌 & あり & 切除側胸骨舌骨筋 & \\
\hline 2 & 女 & 61 & 甲状腺乳頭癌 & あり & 切除側胸骨舌骨筋 & 兩伹反回神経麻痻 \\
\hline 3 & 女 & 74 & 甲状腺乳頭癌 & あり & 非切除側胸骨舌骨筋 & \\
\hline 4 & 男 & 75 & 甲状腺乳頭癌 & あり & 切除側胸骨舌骨筋 & \\
\hline 5 & 女 & 66 & 甲状腺末分化癌 & あり & 非切除側胸骨舌骨筋 & \\
\hline 6 & 女 & 49 & 甲状腺乳頭癌 & あり & 非切除側胸骨舌骨筋 & 鎖骨合併切除 \\
\hline 7 & 男 & 53 & 甲状腺乳頭癌 & あり & 非切除側胸骨舌骨筋 & 肺・肋骨転移 \\
\hline 8 & 男 & 81 & 甲状腺乳頭癌 & あり & 切除側胸骨舌骨筋 & 喉頭浮腫 \\
\hline
\end{tabular}




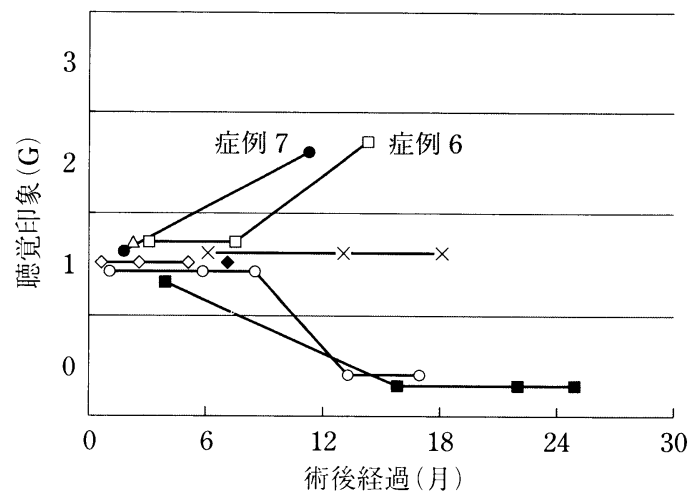

図 2 術後音声の聴覚印象 $(\mathrm{G})$

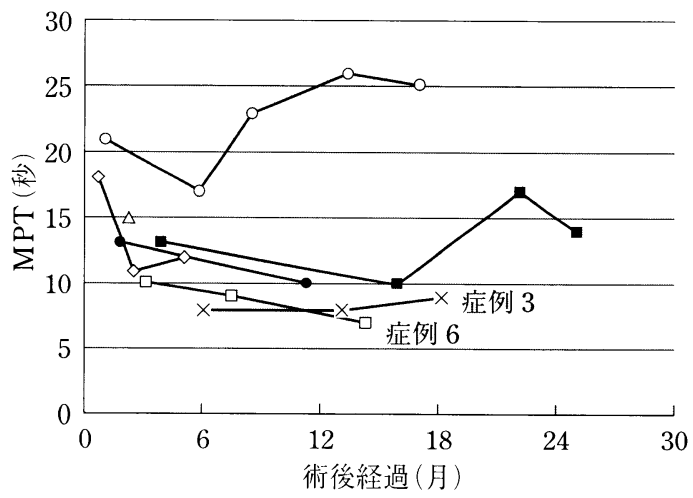

図 3 術後の最長持続発声時間 (MPT)

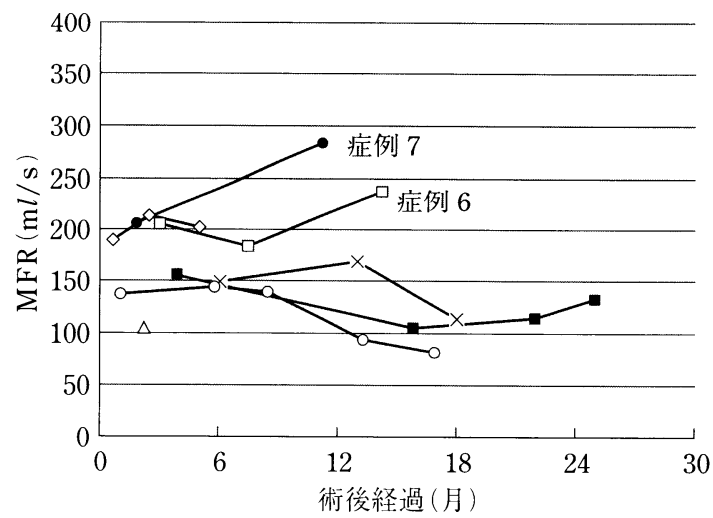

図 4 術後の平均呼気流率 (MFR)

持続発声時間の推移を図 3 に示す。術後早期に良好 な值を示し，いったん悪化した後に，改善したものが 3 例あった. 大多数は 10 秒以上の良好な值を示した が，10 秒未満の例が 2 例あった。 1 例は横隔神経を合 併切除したもの，もう 1 例は鎖骨を合併切除したもの で，いずれも女性であった。

平均呼気流率の推移を図 4 に示す。大多数は 200 $\mathrm{m} l / \mathrm{s}$ 以下の良好な值を示した. ただし, 術後の長期経 過で $250 \mathrm{ml} / \mathrm{s}$ 程度まで悪化したものが 2 例あった。 これらはいずれも非切除側から胸骨舌骨筋を移植した 症例であり, 聴覚印象の悪化例と同じ症例であった。

音声の自己評価では，すべての症例が日常生活や社 会生活に支障をきたさない声であると評価し，他の音 声改善手術や音声治療を希望する症例はなかった。

\section{考察}

一側反回神経麻痺による嗄声の治療は, 現状では, コラーゲンや脂肪などの声帯注射や甲状軟骨形成術， 披裂軟骨形成術が行われることが多い。これらの手術 は声帯を物理的・静的に内方移動する方法であり，神 経の再支配が完成した陳旧性麻痺では妥当な治療法と いえる。

それでは，神経の再支配が生じていない新鮮な麻痺 ではどうであろうか？

選択しえる治療法は以下のごとくであろう。

(1)なにもしないで観察する。

(2)すぐに静的な声帯内方移動を行う.

(3)神経吻合などで神経の適正な再支配を促す。

たとえば，頸部の手術で反回神経を切断し，そのま ま放置した場合，ほとんどの症例では術後に嗄声が生 じる.また，数力月後に音声の改善手術を余儀なくさ れることもしばしば経験する．経過観察のみで嗄声の 改善を期待するのはあまり良い方法とはいえない。

反回神経切除の直後に声帯注射や披裂軟骨内転術を 行い, 術後の嗄声を予防するという報告が散見され る ${ }^{4}$. しかしながら, 喉頭筋への神経再支配に伴って声 帯位が変化し萎縮も進むので, 注射の量や内方移動の 程度を決めるのは実際にはかなり難しい.

反回神経切断時で最も効果的な方法は神経の端々吻 合であると考えられている。実際に，端久吻合を行っ た例では, 声帯はほぼ正中位に固定し声帯萎縮も起こ らず良好な音声が維持される。しかしながら，臨床的 に反回神経の端々吻合が可能な例はほとんどない.甲 状腺癌などの腫瘍浸潤で切除する場合は神経の切除範 囲は数 $\mathrm{cm}$ に及び末梢端が喉頭内に隠れることが少な くない，そこで，頸神経罠と反回神経の末梢端を吻合 して内転筋群への神経支配を促す手術が報告され行わ れている.この手術は, 端々吻合よりも効果は劣るが, ある程度良好な音声が得られるといわれている ${ }^{5,6)}$. た だし，切断端が喉頭内にある場合は，甲状軟骨の部分 的な除去を要し手術操作が煩雑で難しい.

神経筋移植は元来は麻痺筋の再運動化を目的として 考案されたが，一側反回神経麻痺の治療では甲状披裂 
筋の萎縮を改善または防止するために使われてき

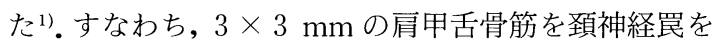
付けたまま採取し, 麻痺側の甲状軟骨板の下半部を切 除して露出した甲状披裂筋の筋腹に埋め込む。この方 法で良好な音声が得られたと報告されている。神経筋 移植は神経吻合とともに麻痺声帯の神経再支配を促す 有力な方法と考えられる.

本論文で報告したわれわれの神経筋移植法は従来の 方法とはかなり異なっている. 第 1 に, 声帯内方移動 の効果を追加するために, $1 \times 2 \mathrm{~cm}$ 程度の比較的大 きな筋を採取する。第 2 に, 麻痺筋に埋め込まずに麻 痺筋が接する傍声門間隙という空間に移植する。第 3 に, 甲状軟骨板を切り取らず僠転・挙上のみでアプロ 一チする。したがって, 本法には, 術直後から良好な 音声が得られ, 甲状軟骨形成術などの追加手術が容易 であるという利点があるが，うまく神経の再支配が生 じるのかという問題もある.

神経再支配の評価には筋電図検査が最適であるが当 科では行っていない. 術後の音声と音声機能の推移か ら検討する。 まず, 音声の聴覚印象, 最長持続発声時 間, 平均呼気流率のいずれでも顕著な悪化例はなかっ た。また, 一部の検査で数力月以降に明らかな改善を 示した例があった。これらは声帯内転筋群への神経再 支配が比較的良好に生じていたことを示すものであ る.すなわち，血行のない神経筋はいずれ萎縮するの で, 声帯内転筋群に神経支配が生じなければ音声・音 声機能の悪化をきたすはずである。したがって，長期 の経過で音声や音声機能に顕著な悪化がなかったこと や一部で改善を認めたのは, 声帯内転筇群に神経再支 配が生じ甲状披裂筋や側輪状披裂筋の緊張が保たれた からと考えられる. 音声検査とともに喉頭ファイバー スコープ検査も行っているが, 声帯萎縮がある例や萎 縮が進行した例はなかった。これも，甲状披裂筋にう まく神経の再支配が生じたことを示す所見である.

本手術の合併症では, 高齢男性の 1 例で術後に喉頭 浮腫が生じた。この例は, 甲状軟骨の骨化が強い症例 で, ビデオ撮影のため比較的長時間, 甲状軟骨の挙上 を続けた。高齢の男性では傍声門間隙の露出は必要最 小限に止めるべきであろう.

本手術の術後経過中に音声の聴覚印象と平均呼気流
率が悪化した例が 2 例あった。 2 例とも反回神経切除 側の筋が使えず反対側から神経筋を廻した症例であっ た.いずれも呼吸機能に問題があり必ずしも喉頭の状 態のみを反映したものとはいえないが, 非切除側から の神経筋移植では神経再支配が生じにくいのかもしれ ない. 今後の検討課題と考えている.

\section{まと め}

1. 喉頭の枠組みを保持し声带内方移動の効果を加 えた神経筋移植術を甲状腺癌の反回神経合併切除例 8 例に行った。

2. 8 例全例が術直後よりほほ良好な音声と音声機 能を示した。非切除側より移植した例では音声がやや 悪化する傾向があった。

3 . 反回神経切除後の嗄声を予防するのに神経筋移 植術は効果的な手術であると考元られた。

\section{文献}

1) Tucker, H.M.: Reinnervation of unilateral paralyzed larynx. Ann Otol Rhinol Laryngol, 86 : 789-794, 1977.

2) 田中信三, 平野 滋, 田辺正博, 他: 神経筋移植 による反回神経切除後の嗄声防止の試み. 耳鼻と 臨床, $48: 365-367,2002$.

3）田中信三, 安里 亮, 平塚康之, 他：反回神経合 併切除時の嗄声予防法一胸骨舌骨筋を用いた神経 筋移植術一. 頭頸部腫瘍, $29 ： 146-150 ， 2003$.

4) McCaffrey, T.V. and Lipton, R.J.: Thyroid carcinoma invading the upper aerodigestive system. Laryngoscope, $100: 824-830,1990$.

5) Crumley, R.L.: Ansa cervicalis to recurrent laryngeal nerve anastomosis for unilateral laryngeal palsy. Laryngoscope, $101: 384-388,1991$.

6）永原國彦：神経吻合・移植術. CLIENT 2114 ：喉 頭 (野村恭也他編), 224-230 頁, 中山書店, 東京, 2001.

別刷請求先： $=606-8507$ 京都市左京区聖護院川原町 54 京都大学大学院医学研究科耳鼻咽喉科 - 頭頸部外科 田中信三 